\title{
14: 104838374-104746670
}

National Cancer Institute

\section{Source}

National Cancer Institute. 14: 104838374-104746670. NCI Thesaurus. Code C41806.

Physical location of BRF1_Gene 